\title{
Ecological Practice: New Understanding on Article XI of Theses on Feuerbach
}

\author{
Jian Gao \\ College of Humanities and Social Sciences \\ Nanjing University of Aeronautics and Astronautics \\ Nanjing, China 210037
}

\begin{abstract}
The Article XI of Theses on Feuerbach writes: "in the past, philosophers only interpreted the world, but the problem was to change the world". This sentence is the most famous and well-known classical quote cited by scholars from Marx's works and it understands Theses on Feuerbach from practice to knowledge to practice. This kind of understanding is not only in accordance with the requirements of Marxist theory, but also better highlights the feature of practice of Marxist philosophy, and provides us with an effective guiding ideology and method for the study of environmental ethics and quantitative ecological practice.
\end{abstract}

Keywords-Theses on Feuerbach; Marx; interpret the world; change the world; practical philosophy; environmental ethics; ecological practice; ecological crisis

\section{INTRODUCTION}

Article XI of Theses on Feuerbach writes: "in the past, philosophers only interpreted the world, but the problem was to change the world". This sentence is the most famous and well-known classical quote cited by scholars from Marx's works.

Marx has achieved a transition from philosophers to communists, and from the foundation of philosophy and theory to the foundation of the real world (history) in Article XI of Theses on Feuerbach. During the transition, the logical development of Marx's theory breaks its philosophical view. Based on the criticism for modern epistemological philosophy, its results help Marx's theory convert into a new area, that is, from consciousness area to practical field.

\section{NEW UNDERSTANDING ON THE ARTICLE Xi OF THESES ON FEUERBACH}

After consulting with the research data, it is found that there is a big difference among researchers on the understanding of the celebrated thesis of Marx. The traditional understanding is that: in the past, because the philosophers before the era of Marx did not understand the meaning of practice and were not aware that social life was essentially practical, they only explained the world in different ways, and focused on interpreted the existing world, but were not committed to changing the existing world. Moreover, through extensive reading and search of information, from the relevant data, it can be seen that many domestic and foreign scholars' understanding of this sentence was that many philosophers tried to "explain the world" in different ways before Marx, but Marxist philosophy changes the previous philosophical concept and clearly states that it not only "explains the world" but also "changes the world". Some scholars even think that philosophy can be divided into two categories, that is, "explaining the world" and "changing the world". They unanimously underline that Marx proposes the "change of the world", that is to say, Marxist philosophy is the philosophy of "changing the world", and other philosophies can only be said to be the philosophy of "explaining the world". This view is very popular, but this is not Marx's original intention, and it is a misunderstanding of Marx's sentence. The author thinks that the focus of the issue is to understand Marx's term "philosophers" thoroughly. It is can be seen from the description of the first ten articles in the Theses on Feuerbach that:

First, the "philosophers" criticized in the Theses on Feuerbach mainly refer to "all previous materialistic" (including Feuerbach's materialism) philosophers, especially those old materialism philosophers based on the "civil" society, capitalist economic relations. Besides, it also refers to the idealism philosophers.

Second, from the shortcomings, errors, one-sidedness, limitations of the "philosophers" criticized in the Theses on Feuerbach, firstly, Marx has pointed out that the all major shortcomings of old materialism and the fundamental mistakes of idealism are that they do not know and understand the significance of revolutionary practice, and critically indicated that they do not understand the meaning of "realistic and perceptual human activities" that "change the world". Next, Marx has criticized the philosophers in the past about the shortcomings of epistemological problem that they do not understand that practice is the basis of objective knowledge and even do not know that test and prove whether knowledge is truth in practice, therefore, a power has generated to force them to "deviate from practice" and singly discuss the reality and truthfulness of thoughts, and they are deeply stuck in the pit of pure scholasticism. Besides, based on his researches and times change, Marx criticizes Helvetius and Robert Owen, the materialists in French, that they emphasize one-sidedly that people are the product of the environment and education, but "forget that the environment is changed by people, and educators themselves must be educated." Finally, Marx also 
criticizes Feuerbach's concept about the nature of human and thinks that he deviates from human social relations on the essence of human beings, and deviates from that people should be practical social life in essence and just observes the errors of the nature of human in isolation and abstractly. Marx thinks the shortcomings of "perceptual materialism" of Feuerbach lie in that "they do not understand the sensibility as practical activity", therefore, "they just can get intuitive understanding on the individuals of "civil society". It is that when they observe the society, they just mechanically get intuitive understanding on the individual in the capitalist economic relations. That is to say, they can only see the activities and roles of the individuals in the capitalist society, but they cannot see the nature of capitalist society and its development law, therefore, they are even less able to see the great power of the proletariat, and even less likely to propose the historical task of revolutionizing the real society through the practice of the proletarian revolution, overthrowing the capitalist system, and establishing a new communist society.

From the above criticisms, it can be obviously seen that the philosophers before the era of Marx could not actually understand the true meaning of revolutionary practice, therefore, they could not accurately understand and cope with the relationship between knowledge and practice, the relationship between human and environment and education, and even could not fully know the human essence and the nature of social life, therefore, they could not devote themselves to the revolution and transformation for secular society and capitalist society, in other words, they just "interpreted the world by other ways".

Third, Marx has expounded a series of concepts about new materialism in Theses on Feuerbach. These viewpoints include: learn about things, sensibility and reality from the subject level; the theory of practice is to believe that practice is the basis of knowledge and practice is the sole criterion for testing truth; the revolutionary practice views that human activities are consistent with environmental changes; human nature is the sum of all social relations; practice is the essence of social life; The foothold of new materialism is to fight for the proletarian liberation in the whole world; the above statements can be summarized as the viewpoints of practice. As the practical theories are the basic concepts of Marxism's new materialism, the fundamental task and historical mission of Marxist philosophy is to understand the world through the practice of "changing the world" and carry out practice to "change the world" according to this correct knowledge, so as to liberate all humanity and achieve communism.

In addition, does the word "philosophers" refer to all the philosophers before the era of Marx or the specific philosophical schools? Some scholars in China have different opinions, and they think that it refers to the latter rather than the former. Specifically, they think that "philosophers" refer to the "Young Hegelians" produced in the process of disintegration of Hegelianism, that is, the "philosophers" of Young Hegelians who just interpret the world by different methods and cannot actually change the world. Actually, Marx does not completely deny the philosophers before him who just interpret the world but not advocate changing the world. In The Holy Family, Marx says that the criticisms made by materialists and communists of France and England can be regarded as "the objects that are not beyond the human beings and in other sides, and are not abstract or personalized". This kind of criticisms belongs to the actual human activities conducted by individuals who are active members of society. These individuals, as human beings, also have pain, feelings, thoughts, and actions. Therefore, their criticisms also are practiced and their communism is such a kind of socialism where they put forward practical and clear physical measures. In this society, they not only think but also take actions.

\section{UNDERSTANDING THAT THEORY ROOTS FROM LIFE AND CONVERTS TO LIFE IN MULTI-VIEW}

The viewpoints of Marx are not to understand the laws of the objective world to explain the world, but to be able to take this knowledge of objective laws to actively change the world, and to deeply recognize the essential difference from the old philosophy, or the former philosophy. For Marx, it is important to make a scientific explanation of the existing world, but more significantly, we should put the theory into practice and actually oppose and change the existing world. There is no doubt that this kind of understanding has its merits.

In a word, to correctly and comprehensively understand the Article XI of Theses on Feuerbach, we should choose the first ten articles of Theses on Feuerbach by Marx and writings before and after the completion of Theses on Feuerbach as basis, instead of subjective guess. Based on Marx's own statement that "the philosophers only explain the world in different ways", and they mainly criticize German classical philosophers, especially the young Hegelians including Feuerbach. They do not understand the significance of revolutionary practice, only have intuitive understanding on the individuals in capitalist society, and just recognize everything that exists in different ways, and hope to achieve a correct understanding of existing facts, and regard the abstract and isolated "human" as the driving force of history, and turn the whole history into a process of consciousness development. The first half sentence of Marx fundamentally criticizes the common defects of all idealism and old materialism, that is, historical idealism. The latter part of the sentence, "the problem was to change the world", refers to the "new materialism" created by Marx is exactly the opposite of old materialism and idealism. This ultimately reveals the essential characteristics, fundamental tasks, and historical mission of Marxist philosophy.

Based on the times, Marxism is not only a philosophy, but also a programme of political change and even the whole social change, which embodies the organic unity of speculation and experience, and scientificity and revolutionary. However, the difficulty of this understanding is quite obvious. Can we say that the former Marxist philosophers do not pay attention to actually changing the existing world? Obviously not. From my personal view, the birth of any school has the goal or wish to interfere the reality.

The author believes that the understanding of this sentence of Marx can be studied from multiple perspectives in order to be complete, comprehensive and accurate. However, it is particularly important to understand from Marx's own 
thoughts and statement, rather than relying on our own subjective guesses. We should have such a minimum down-toearth attitude.

Based on the referred information, in fact, these explanations all remain in the framework of "theory-practice" to understand Article XI of Theses on Feuerbach, focusing on the deductions from theory to practice, and are not consistent with the basic clues in the first articles of Theses on Feuerbach. As we all know, the theme of modern philosophy is epistemology. In Theses on Feuerbach, Marx starts from this basic issue to criticize old materialism and idealism. Marx is subtly aware that the settlement of this problem not only relies on the theory, but also on the practice. Therefore, in Article II of Theses on Feuerbach, he points out that people should prove the truth and reality of their thinking in practice, and "this is not a theoretical issue but a practical issue". Marxist philosophy is to put theory back to practice, so it has been constantly tested, supplemented and perfected, and then it is correct.

Therefore, the understanding of Article XI of Theses on Feuerbach should not be confined to the thinking framework of "theory - practice", but should be seen from the perspective of "practice-cognition (theory)-practice". The former only pays attention to the transformation from theory to reality, and the latter not only sees the importance of the transformation from theory to reality, but also sees that theory originates from reality.

\section{ECOlOGICAL PRACTICE UNDER THE FRAMEWORK OF "Practice - Cognition (THEORY) - Practice"}

Article XI of Theses on Feuerbach provides an effective guiding ideology and method for us to learn environmental ethics at present. With this guiding ideology and method, it is of great importance for our major to construct theoretical systems, conduct practical cooperation, and conduct quantitative research in the course of further research in the future.

The debate on non-anthropocentrism (ecocentrism) and anthropocentrism in environmental ethics has existed for a long time. Non-anthropocentrism (ecocentrism) strongly opposes the standpoint of "anthropocentrism", and advocates viewpoints of "respecting nature" and "the rights of nature", which is not persuasive in theory. If it must be put into practice, it is harmful. It is not surprising that there is a radical trend of thought such as ecocentrism when environmental issues do not cause sufficient social attention. To some extent, this radical trend of thought can also play a certain role in promoting environmental protection. However, when environmental problems have been gradually recognized and valued, the negative impact of this radical trend of thought must arouse our high vigilance.

After the Rio Conference on Environment Development in 1992, the Chinese government immediately organized experts and personnel to compile and approve the China's Agenda 21. This document became the first national program of action in the world and was actively evaluated by the international community. After that, based on this, Chinese government also compiled the Ninth Five-Year Plan from 1996 to 2000 and
Long-term Development Plan for 2010 to guide the national environmental protection practice. However, by contrast, our theoretical research on environmental protection (including environmental ethics research) lags behind and is basically in a spontaneous and decentralized state, let alone walk in front of practice to guide practice.

Some environmental ethicists lack meticulous attention and focused research on China's real environmental problems. They often talk about the rights of animals in a romantic way of thinking, express their religious feelings, discuss abstractly the equal relationship between man and nature, and even advocate the wilderness experience. As the highest administrative department in the field, although the State Environmental Protection Administration intends to combine the scientific research of the scholars with the actual work of the department, there are insufficient efforts for various reasons. As far as environmental ethics education and science popularization activities are concerned, they are far from meeting practical requirements. The state environmental protection department and the education department also have failed to jointly formulate a planned and systematic education plan for the general public, especially for primary and middle school students. Environmental ethics researchers and educational departments have not been well combined to carry out the research on the theory and practice of environmental ethics education, so as to provide content and methods for environmental ethics education at different levels and types. In contrast, civil environmental protection organizations such as "Friends of Nature" often hold some colorful environmental protection activities, and are paid attention to by the society. However, their activities cannot be carried out better and more widely because of funding difficulties and other issues.

Therefore, the author believes that we must take the practice of socialist modernization as the cornerstone before the construction of environmental ethics with Chinese characteristics, the inheritance and criticism of the environmental ethics in ancient and modern times, the summary of the actual environmental ethical phenomena, the formulation and advocation of what kinds of ecological environmental moral principles and ecological environmental moral norms, and the application of ecological ethics to regulate the moral relationship between people (that is, between the enterprises and masses where the enterprises are located, between manufacturer, seller and consumers, between the scientific research institution and the environmentalist, between the enterprises, between governments at different regions, between the masses at different regions, between decision making agency and the masses, and between contemporary people and future generations). Environmental ethicists must strengthen cooperation with environmental protection management departments, education departments, and civil environmental protection organizations. Only in this way can it be the key to further integrating theoretical research and practical activities that promote environmental protection in China.

Environmental ethics should now be a prestigious doctrine. However, this discipline has been trapped in the embarrassment of practice and theory in a short history. On the one hand, various non-anthropocentrism doctrines are mainly 
followed by some radical environmental organizations, which are difficult to have a substantial impact on the environmental decisions of the mainstream society. On the other hand, almost every theory of non-anthropocentrism has some defects that cannot be overcome, which cannot be justified. How to reach an effective path from practice to theoretical understanding to solve various constitution theories and substantive problems of non-anthropocentrism become an effective method "theorypractice" provided by Theses on Feuerbach. It can open a new thought to learn environmental ethics by learning Article XI of Theses on Feuerbach.

\section{CONCLUSION}

"The Outline of Feuerbach" opens up new ideas for the theory and practice of ecological civilization construction. General Secretary Xi Jinping pointed out: "We need clear watger and green mountains, as well as gold mountains and silver mountains. We prefer blue water and green mountains to gold mountains and silver mountains, and blue water and green mountains are gold mountains and silver mountains." This is in line with Marx's "revolutionary, and practical critique activity", which corrects the unscientific practice in the transformation of human and natural material. Development is the key to solving all problems in China. In the process of development, the necessity and urgency of ecological civilization construction can be seen clearly. The combination of theoretical understanding and ecological practice of building a beautiful China can truly respect nature and ultimately realize the dialectical unity of historical nature and natural history, and thus realize the great rejuvenation of the Chinese nation.

\section{REFERENCES}

[1] Yu Mouchang, Wang Yaoxian. Environmental Ethics. Beijing: Higher Education Press [M], 2004.

[2] Wang Guopin. The Wisdom of survival-Theory and Practice of Environmental Ethics. Beijing: China Forestry Publishing House [M], 1998.

[3] Gao Jian. On Ecological Moral and All-round Development of Human Beings [J]. Journal of Shandong Agricultural Administrators' College, 2007 (1).

[4] Wu Yong, Tang Jingxin, Gao Jian. Comments on Anthropocentrism in Dispute and Disagreement [J]. Journal of Shandong Agricultural Administrators' College, 2009 (3)

[5] Insisting on the Concept That Beautiful Scenery Is the Gold and Silver Mines, and Vigorously Enhancing the Level of Ecological Civilization Construction [N]. People's Daily, 2016-12-09. 